\title{
FAKTOR-FAKTOR YANG MEMPENGARUHI PERSEPSI SISWA SMP SARASWATI SINGARAJA TERHADAP EVALUASI PEMBELAJARAN IPS TERPADU PADA TAHUN AJARAN 2017/2018
}

\author{
Luh Herlin1, I Wayan Suwendra1, Iyus Akhmad Haris2 \\ Jurusan Pendidikan Ekonomi, Fakultas Ekonomi \\ Universitas Pendidikan Ganesha \\ Singaraja, Indonesia
}

e-mail :\{elinherlin123@gmail.com, yc9eda@yahoo.co.id, akhmad.haris@undiksha.ac.id\}

\begin{abstract}
Abstrak
Penelitian ini bertujuan untuk mengetahui faktor-faktor yang mempengaruhi persepsi siswa SMP Saraswati Singaraja dan faktor yang paling dominan mempengaruhi persepsi siswa SMP Saraswati Singaraja terhadap evaluasi pembelajaran IPS Terpadu pada tahun ajaran 2017/2018. Jenis penelitain ini adalah penelitian kuantitatif dengan rancangan faktorial. Populasi dalam penelitian ini adalah seluruh siswa SMP Saraswati Singaraja yang berjumlah 109 siswa dan sampel ditentukan sebanyak 86 siswa yang diambil dengan menggunakan teknik random sampling. Metode pengumpulan data yang digunakan adalah dokumentasi dan kuesioner. Data dianalisis menggunakan analisis faktor dengan program SPSS 16,0 for windows. Hasil penelitian menunjukkan bahwa faktor yang mempengaruhi persepsi siswa SMP Saraswati Singaraja terhadap evaluasi pembelajaran IPS Terpadu pada tahun ajaran 2017/2018 yaitu faktor internal meliputi, faktor psikologis dengan nilai variance sebesar $56,578 \%$ dan faktor eksternal meliputi, faktor objek dengan nilai variance sebesar $23,767 \%$ dan faktor lingkungan dengan nilai variance sebesar $19,656 \%$. Faktor internal meliputi faktor psikologis menjadi faktor yang paling dominan, karena memiliki variance explained tertinggi yaitu sebesar $56,578 \%$, artinya bahwa faktor internal meliputi faktor psikologis mampu menjelaskan persepsi siswa sebesar $56,578 \%$.
\end{abstract}

Kata kunci:Faktor Persepsi Siswa, Evaluasi Pembelajaran

\begin{abstract}
This study was aimed at determining the factors that influence the students of SMP Saraswati Singaraja' perception and the most dominant factor that influence the students of SMP Saraswati Singaraja' perception toward the evaluation of Integrated IPS learning in 2017 / 2018. The type of this study was quantitative research with factorial design. The population of this study was all students of SMP Saraswati Singaraja which were 109 students and the sample was determined as many as 86 students were drawn using a random sampling technique. The methods of data collection used were documentation and questionnaire. The data were analyzed using factor analysis which was SPSS 16.0 for windows program. The result of this research showed that factors influencing the students of SMP Saraswati Singaraja' perception toward the evaluation of Integrated IPS learning in academic year 2017/2018 were internal factor include, psychological factor with variance value equal to $56,578 \%$ and external factor include factor objects with the variance value of $23.767 \%$ and environmental factors with the variance value of $19.656 \%$. Internal factors include psychological factor became the most dominant factor, because it had the highest variance explained that was equal to $56,578 \%$, it meant that internal factor include psychological factor were able to explain students' perception $56,578 \%$.
\end{abstract}

Keywords:Students' Perception Factor, Learning Evaluation 


\section{PENDAHULUAN}

Pendidikan merupakan peningkat kualitas hidup manusia agar dapat mengembangkan potensi yang ada di dalam dirinya. Menurut Hamalik (2008:3) "pendidikan adalah suatu proses dalam rangka mempengaruhi peserta didik supaya mampu menyesuaikan diri sebaik mungkin dengan lingkungannya dan dengan demikian akan menimbulkan perubahan dalam dirinya sehingga memungkinkannya untuk berfungsi dalam kehidupan masyarakat." Lembaga pendidikan (sekolah) memegang peranan yang cukup penting dalam proses pendidikan. Guru sebagai pelaksana pendidikan berperan sebagai pendidik sekaligus fasilitator yang mengarahkan siswanya untuk mencapai keberhasilan belajar. Untuk mencapai keberhasilan belajar, guru dituntut secara profesional untuk dapat mengembangkan kegiatan pembelajaran.

Dalam sistem pembelajaran, evaluasi merupakan salah satu faktor yang sangat penting. Menurut Sudaryono (2012:38) "evaluasi (evaluation) yaitu suatu rangkaian kegiatan yang dirancang untuk mengukur efektivitas sistem pembelajaran secara keseluruhan." Sedangkan menurut Astiti (2017:2), "evaluasi merupakan kegiatan identifikasi untuk melihat apakah suatu program yang telah direncanakan telah tercapai atau belum, berharga atau tidak, serta dapat pula digunakan untuk melihat tingkat efisiensi pelaksanaannya." evaluasi pembelajaran adalah suatu proses atau kegiatan yang sistematis, berkelanjutan, dan menyeluruh yang dirancang untuk mengukur dan melihat efisiensi sistem pembelajaran yang melibatkan aspek intelektual emosional, dan sosial melalui kegiatan belajar mengajar.

Evaluasi pembelajaran dilakukan untuk mengetahui sampai sejauh mana efisiensi proses pembelajaran dilaksanakan dan efektifitas pencapaian tujuan pembelajaran yang telah ditetapkan. Selain itu juga dilakukan untuk merangsang kegiatan siswa dalam menempuh program pendidikan (Sudaryono, 2012). Evaluasi mencakup sejumlah teknik yang tidak bisa diabaikan oleh seorang guru dan evaluasi bukanlah sekumpulan teknik semata-mata, tetapi evaluasi merupakan suatu proses berkelanjutan yang mendasari keseluruhan kegiatan pembelajaran yang baik.

Keberhasilan evaluasi pembelajaran tergantung pada kemampuan pengajar dalam merencanakan, melaksanakan, mengolah, dan melaporkannya sesuai prosedur evaluasi yang benar. Selain itu, keberhasilan evaluasi pembelajaran juga tergantung pada siswa yang akan menjalankan evaluasi tersebut. Dalam menjalankan evaluasi pembelajaran, setiap siswa pastinya memiliki persepsi, baik persepsi positif maupun negatif. Persepsi yang tercipta merupakan proses pemahaman terhadap evaluasi yang dilakukan. Selain itu juga akan mempengaruhi sikap siswa dalam pelaksanaan evaluasi pembelajaran.

Istilah persepsi sering dikatakan sebagai suatu pandangan atau anggapan seseorang terhadap suatu objek. Menurut Walgito (2003:54) "persepsi merupakan proses pengorganisasian, penginterpretasian terhadap stimulus yang diterima oleh organisme atau individu sehingga merupakan sesuatu yang berarti, dan merupakan aktivitas yang integrated dalam diri individu." Persepsi adalah kemampuan otak dalam menerjemahkan stimulus atau proses untuk menerjemahkan stimulus yang masuk ke dalam alat indera manusia (Sugihartono, dkk. 2007). Ikhsan dan Ishak (2008:175) menyatakan, "persepsi adalah proses di mana individu mengatur dan menginterpretasikan kesankesan sensoris mereka guna memberikan arti bagi lingkungan mereka." Persepsi merupakan suatu proses dan konsep dalam ilmu psikologi yang menyatakan sebuah proses individu mengatur dan menginterpretasikan kesan-kesan sensorik mereka guna memberikan arti bagi lingkungan mereka (Robbins dan Judge, 2008).

Dari pernyataan di atas, maka dapat disimpulkan bahwa persepsi merupakan pandangan dan proses aktivitas seseorang dalam memberikan kesan, penilaian, pendapat, dan mengintepretasikan kesankesan sensoris berdasarkan informasi yang diterima melalui alat indera. Dalam mempersepsi suatu stimulus, hasil persepsi mungkin akan berbeda antara individu satu 
dengan individu lain meskipun stimulus yang dipersepsikan sama.

Menurut Walgito (2010), proses persepsi berlangsung seperti, pertama stimulus mengenai alat indera, merupakan proses yang bersifat kealaman (fisik). Kedua stimulus kemudian dilangsungkan ke otak oleh syaraf sensoris, proses ini merupakan proses fisiologis. Ketiga di otak sebagai pusat susunan urat syaraf terjadilah proses yang akhirnya individu dapat menyadari atau mempersepsi tentang apa yang diterima melalui alat indera. Proses yang terjadi dalam otak ini merupakan proses psikologis.

Sedangkan Thoha (2003) menyatakan, proses terbentuknya persepsi didasari pada beberapa tahapan yaitu, pertama stimulus atau rangsangan, terjadinya persepsi diawali ketika seseorang dihadapkan pada suatu stimulus/rangsangan yang hadir dari lingkungannya. Kedua registrasi, dalam proses registrasi, suatu gejala yang nampak adalah mekanisme fisik yang berupa penginderaan dan syarat seseorang berpengaruh melalui alat indera yang dimilikinya. Seseorang dapat mendengarkan atau melihat informasi yang terkirim kepadanya, kemudian mendaftar semua informasi yang terkirim kepadanya tersebut. Ketiga interpretasi, interpretasi merupakan suatu aspek kognitif dari persepsi yang sangat penting yaitu proses memberikan arti kepada stimulus yang diterimanya. Proses interpretasi tersebut bergantung pada cara pendalaman, motivasi, dan kepribadian seseorang.

Jadi, persepsi itu awalnya merupakan proses ditangkapnya stimulus (objek) melalui alat indera (reseptor) dan diteruskannya stimulus yang diterima alat indera melalui saraf-saraf sensoris otak. Akhirnya individu dapat menyadari atau mempersepsi tentang apa yang diterima melalui alat indera. Dalam proses persepsi individu akan menginterpretasikan stimulus bergantung pada cara pendalaman, motivasi, dan kepribadian individu tersebut.

Kemampuan seseorang untuk mempersepsi suatu objek dipengaruhi oleh beberapa faktor seperti pengetahuan, harapan, pengalaman, dan lain-lain. Faktorfaktor yang mempengaruhi persepsi menurut Robbins \&Judge (2008:176), yaitu "faktor- faktor dalam diri si pengarti, faktorfaktor dalam situasi, dan faktor-faktor dalam diri target." Sugihartono, dkk. (2007:9) menyatakan "adanya hasil persepsi dipengaruhi oleh pengetahuan, pengalaman atau wawasan seseorang, kebutuhan seseorang, kesenangan atau hobi seseorang, dan kebiasaan dan pola hidup sehari-hari." Sedangkan menurut Walgito (2003) faktor yang mempengaruhi persepsi yaitu, faktor internal (yang berhubungan dengan segi psikologis) dan faktor eksternal (objek dan lingkungan). Dalam mempersepsi suatu objek, hasil persepsi mungkin akan berbeda, meskipun objek yang dipersepsikan sama.

Persepsi seseorang atau sekelompok orang tentang objek atau fenomena sosial diukur dengan menggunakan skala Likert. Menurut Sugiyono (2010:93), "skala Likert digunakan untuk mengukur sikap, pendapat, dan persepsi seseorang atau sekelompok orang tentang fenomena sosial." Sedangkan Mulyatiningsih (2012) menyatakan, skala Likert merupakan suatu skala psikometrik yang umumnya digunakan dalam kuesioner.Jadi, Skala Likert digunakan oleh para peneliti untuk mengukur persepsi atau sikap seseorang.

SMP Saraswati Singaraja merupakan salah satu sekolah swasta beralamat di Jalan Bisma No. 4 Singaraja yang bernaung di bawah Yayasan Saraswati. Jumlah siswa SMP Saraswati Singaraja pada tahun ajaran 2017/2018 sebanyak 109 siswa yang memiliki karakteristik yang berbeda-beda dalam menerima dan memahami materi pelajaran. Berdasarkan hasil observasi awal yang dilakukan oleh peneliti di kelas VII khususnya pada mata pelajaran IImu Pengetahuan Sosial (IPS) Terpadu menunjukkan bahwa, dalam pelaksanaan evaluasi pembelajaran hanya $38 \%$ siswa yang bersungguh-sungguh mengikuti kegiatan evaluasi pembelajaran dan sisanya sebanyak $62 \%$ siswa kurang bersungguh-sungguh mengikutinya.

Kondisi tersebut dipertegas oleh guru mata pelajaran IPS Terpadu yang menyatakan bahwa rata-rata kemampuan siswanya tergolong rendah. Hal ini terlihat dari aktivitas siswa kurang bersungguhsungguh dalam menjalankan evaluasi pembelajaran, sehingga perlu strategi yang 
lebih agar siswa nya mampu menguasai materi pelajaran. Guru sering mengadakan evaluasi dalam pembelajaran agar dapat digunakan sebagai masukan bagi guru dalam memperbaiki dan menyempurnakan proses pembelajaran. Selain melakukan wawancara dengan guru mata pelajaran IPS Terpadu, peneliti juga melakukan wawancara dengan 52 siswa yang terdiri dari kelas VII, VIII, dan IX. Sebanyak 19 $(36,5 \%)$ siswa menyatakan senang diadakannya evaluasi pembelajaran, mereka menganggap dengan adanya evaluasi pembelajaran dapat membuat semangat belajar dan menambah nilai pelajaran, sebanyak $12(23,1 \%)$ siswa menyatakan biasa saja kalau diadakan evaluasi pembelajaran, dan sebanyak 21 $(40,4 \%)$ siswa menyatakan kurang senang diadakannya evaluasi pembelajaran terutama pemberian kuis-kuis yang dilakukan di akhir pembelajaran, mereka menganggap soal evaluasi pembelajaran sulit untuk dijawab dan waktu pengerjaan yang terlalu sedikit.

Berdasarkan dari uraian latar belakang di atas, maka peneliti tertarik untuk melakukan penelitian mengenai faktor-faktor yang mempengaruhi persepsi Siswa SMP Saraswati Singaraja terhadap evaluasi pembelajaran IPS Terpadu pada tahun ajaran 2017/2018.

\section{METODE}

Penelitian ini dilakukan di SMP Saraswati Singaraja yang beralamat di Jalan Bisma No. 4 Singaraja. Jenis data yang digunakan dalam penelitian ini adalah data kuantitatif. Menurut Firdaus (2012) penelitian kuantitatif dapat diartikan sebagai penelitian yang menggunakan angka (numerical) dari hasil observasi dengan maksud untuk menjelaskan fenomena dari observasi. Data kuantitatif dalam penelitian ini adalah skor jawaban responden dengan kategori angka 1-5 yang diperoleh dari hasil penyebaran kuesioner mengenai faktorfaktor yang mempengaruhi persepsi siswa SMP Saraswati Singaraja terhadap evaluasi pembelajaran IPS Terpadu pada tahun ajaran 2017/2018.

Sumber data dalam peneitian ini adalah data primer, yaitu data yang diperoleh pertama kali oleh peneliti dengan cara menyebarkan kuesioner dan melakukan wawancara secara langsung dengan pihak-pihak yang berhubungan dengan penelitian yang dilakukan, yaitu Kepala Sekolah, Guru, Staff Tata Usaha, dan Siswa SMP Saraswati Singaraja dan data sekunder, yaitu diperoleh dari dokumen yang terarsif oleh staf Tata Usaha SMP Saraswati Singaraja, seperti nama dan jumlah siswa.

Metode pengumpulan data yang digunakan dalam penelitian ini adalah dokumentasi dan kuesioner. Metode dokumentasi adalah pengumpulan data dengan membaca atau mencatat dokumen dari Staf Tata Usaha. Dokumentasi digunakan untuk mendapatkan data berupa nama dan jumlah siswa SMP Saraswati Singaraja. Sedangkan kuesioner adalah cara pengumpulan data dengan menggunakan daftar pernyataan yang ditujukan kepada responden. Pengumpulan data dari responden dilakukan untuk memperoleh data mengenai faktor-faktor yang mempengaruhi persepsi siswa SMP Saraswati Singaraja terhadap evaluasi pembelajaran IPS Terpadu pada tahun ajaran 2017/2018.

Instrumen yang digunakan dalam penelitian ini adalah kuesioner yang dirancang dengan menggunakan skala Likert dengan skor 1-5 untuk pernyataan positif dan pernyataan negatif. Untuk pernyataan positif dengan kategori sangat setuju (SS) diberikan skor 5 , setuju (S) diberikan skor 4, kurang setuju (KS) diberikan skor 3, tidak setuju (TS) diberikan skor 2, dan sangat tidak setuju (STS) diberikan skor 1 . Sedangkan untuk pernyataan negatif dengan kategori sangat setuju (SS) diberikan skor 1, setuju (S) diberikan skor 2, kurang setuju (KS) diberikan skor 3, tidak setuju (TS) diberikan skor 4, dan sangat tidak setuju (STS) diberikan skor 5 .

Sebelum instrumen digunakan, terlebih dahulu harus diuji. Pengujian instrument penelitian dilakukan dengan uji validitas dan uji reliabilitas. Validitas adalah suatu ukuran yang menunjukkan tingkattingkat kevalidan suatu instrumen. Uji validitas menunjukkan suatu kuesioner mampu untukmengungkapkan sesuatu yang akan diukur oleh kuesioner tersebut. 
Suatu kuesioner dikatakan valid jika kuesioner dapat mengungkapkan sesuatu yang diukur oleh kuesioner tersebut. Untuk menetukan valid atau tidak, maka akan dilakukan dengan cara membandingkan antara nilai $r_{\text {hitung }}$ danr $_{\text {tabel }}$ dengan taraf signifikan yang digunakan yaitu $5 \%$. Apabila $r_{\text {hitung }}>r_{\text {tabel }}$, maka instrumen dikatakan valid, sebaliknya jika $r_{\text {hitung }}<r_{\text {tabel }}$ maka instrumen dapat dikatakan tidak valid. Dalam membantu proses pengolahan data secara cepat dan tepat, maka pengolahan data untuk uji validitas dilakukan dengan program Statistic Product and Service Solution (SPSS) 16.0 for Windows.

Uji reliabilitas merupakan ukuran yang menunjukkan konsistensi dari alat ukur dalam mengukur gejala yang sama pada waktu yang berbeda. Untuk menentukan reliabel tidaknya instrumen adalah dengan mengonsultasikan hasil $r_{\text {hitung }}$ dengan taraf signifikan 5\%. Apabila $r_{\text {hitung }} \geq r_{\text {tabel }}$ maka dikatakan reliabel, sebaliknya jika $r_{\text {hitung }}$ $\leq r_{\text {tabel }}$ maka dikatakan tidak reliabel. Dalam membantu proses pengolahan data secara cepat dan tepat, maka pengolahan data untuk uji reliabilitas menggunakan uji Cronbach's Alpha dilakukan dengan program Statistic Product and Service Solution (SPSS) 16.0 for Windows.

Sebelum menganalisis data, terlebih dahulu melakukan proses transformasi data ordinal ke data interval. Karena data yang diperoleh dari kuesioner adalah data ordinal. Agar dapat mengui hipotesis, data tersebut diubah menjadi data interval melalui Metode Suksesif Interval (MSI) pada Microsoft Office Excel 2007. Metode analisis data yang digunakan dalam penelitian ini adalah model analisis faktor. Menurut Supranto (2010:113) "analisis faktor adalah serangkaian prosedur yang digunakan untuk mengurangi dan meringkat data tanpa kehilangan informasi penting atau mereduksi data dari variabel yang jumlahnya lebih sedikit." Analisis faktor digunakan untuk mengetahui faktor-faktor yang mempengaruhi persepsi siswa SMP Saraswati Singaraja terhadap evaluasi pembelajaran IPS Terpadu pada tahun ajaran 2017/2018 dengan menggunakan software SPSS. Suliyanto (2005) menyatakan langkah-langkah dalam analisis faktor terdiri dari enam langkah.
Pertama membuat matrik korelasi, proses analisis faktor didasarkan pada matrik korelasi antara variabel yang satu dengan variabel-variabel lain, sehingga dapat dikeluarkan dari analisis. Untuk menguji ketetapan model analisis faktor, maka dapat digunakan Bartlett's test of sphericity yang dipakai untuk menguji bahwa variabel-variabel dalam sampel berkorelasi. Hasil Bartlett's test of sphericity menunjukkan apakah hubungan antara variabel-variabel signifikan atau tidak. Statistik lain yang berguna adalah pengukuran kelayakan sampel Kaiser Meyer Olkin (KMO). Analisis faktor dianggap layak jika besaran KMO nilainya minimal 0,50 . Besaran ini digunakan untuk mengukur derajat korelasi antar variabel dengan kriteria Measure of Sampling $\operatorname{Adequacy}(M S A) \geq 0,50$.

Kedua penetapan jumlah faktor, penentuan jumlah faktor yang ditentukan untuk mewakili variabel-variabel yang akan dianalisis didasarkan pada besarnya eigenvalue serta persentase total variannya. Hanya faktor yang memiliki eigenvalue sama atau lebih besar dari satu yang dipertahankan dalam model analisis faktor, sedangkan yang lainnya dikeluarkan dari model. Ketiga rotasi faktor, hasil dari ekstraksi faktor dalam matriks faktor mengidentifikasi hubungan antar faktor dan variabel individual, namun dalam faktorfaktor tersebut banyak variabel yang berkorelasi sehingga sulit diinterpretasikan. Melalui rotasi faktor matriks, faktor matriks ditransformasikan ke dalam matriks yang lebih sederhana sehingga mudah diinterpretasikan. Rotasi faktor menggunakan prosedur varimax.

$\begin{array}{lr}\text { Keempat interpretasi } & \text { faktor, } \\ \text { interpretasi faktor dilakukan } & \text { dengan } \\ \text { mengklasifikasikan } & \text { variabel yang }\end{array}$ mempunyai factor loading minimum 0,5 sedangkan variabel dengan factor loading kurang dari 0,5 dikeluarkan dari model. Kelima penyeleksian surrogate variable, mencari salah satu variabel dalam setiap faktor sebagai wakil dari masing-masing faktor. Pemilihan ini didasarkan pada nilai factor loading tertinggi.

Keenam model fit (ketepatan model), tahap akhir dari analisis faktor adalah mengetahui ketepatan dalam memilih teknik 
analisis faktor antara principal component analysis dan maximum likelihood dengan melihat jumlah residual (perbedaan) antara korelasi yang diamati dengan korelasi yang diproduksi. Semakin kecil persentase nilai residual dalam hal ini adalah nilai Root Mean Square Error (RMSE), maka semakin tepat penentuan teknik tersebut.

\section{HASIL DAN PEMBAHASAN Hasil}

Faktor-faktor yang mempengaruhi persepsi siswa SMP Saraswati Singaraja terhadap evaluasi pembelajaran IPS Terpadu pada tahun ajaran 2017/2018.

Analisis faktor digunakan untuk menganalisis hipotesis penelitian dengan memasukkan semua total nilai dari seluruh dimensi-dimensi yang ada pada faktorfaktor tersebut terhadap total skor item. Skor dari masing-masing faktor yang dijabarkan ke dalam dimensi-dimensi terlebih dahulu ditransformasikan ke dalam data interval, kemudian dilakukan langkahlangkah dalam analisis faktor antara lain: membuat matrik korelasi, penetapan jumlah faktor, rotasi faktor, interpretasi faktor, penyeleksian surrogate variable, dan model fit (ketepatan model).

Selanjutnya untuk mengukur kecukupan sampel yang dalam penelitian ini digunakan Kaiser-Mayer-Oilkin (KMO) and Bartlett's Test of Sphericity yang tujuannya untuk menguji derajat interkorelasi antara variabel dan ketepatan pemakaian analisis faktor serta untuk mengetahui kecukupan sampel atau pengukuran kelayakan sampel pada analisis faktor dengan syarat jika nilai KMO $>0,5$ dan uji Bartlett's Test of Sphericity apabila nilai signifikan $<5 \%$. Adapun hasil uji KMO dan Bartlett's Test of Sphericity seperti nampak pada tabel 1 berikut.
Tabel 1. Hasil Analisis KMO and Bartett's Test of Sphericity $\mathrm{KMO}$ and Bartlett's Test

Kaiser-Meyer-Olkin Measure of ${ }^{6} 635$
Sampling Adequacy.

Bartlett's Test Approx. Chi-Square of Sphericity

Df 28.061

Sig.

Berdasarkan tabel 1, dapat dijelaskan bahwa hasil analisis faktor diperoleh nilai KMO sebesar 0,635 dengan demikian angka KMO Measure of Sampling Adequacy menunjukkan lebih besar dari 0,50 . Hal ini berarti bahwa jumlah sampel yang digunakan dalam penelitian ini sudah memenuhi syarat dalam melakukan analisis faktor dan metode analisis faktor tepat digunakan untuk menganalisis data yang diperoleh. Hasil pengujian Bartlett's Test of Sphericity menunjukkan hasil penelitian yang signifikan pada taraf nyata 0,000 . Hal ini berarti matrik korelasi memiliki korelasi yang signifikan dengan sejumlah variabel, karena nilai signifikansi lebih kecil dari 0,05.

Pada hasil output Statistic Product and Service Solution (SPPS) for Windows versi 16.0, pengujian Measure of Sampling Adequacy (MSA), dapat diketahui faktorfaktor atau variabel yang layak digunakan dalam analisis faktor. Pada output SPSS (Anti-image Matrices), terdapat kode "a" yang artinya tanda untuk Measure of Sampling Adequacy (MSA). Faktor yang layak digunakan dalam analisis faktor adalah faktor yang memiliki nilai MSA > 0,50 . Apabila terdapat faktor memiliki nilai MSA < 0,50, maka faktor tersebut dikeluarkan agar dapat dilakukan analisis faktor. Adapun nilai MSA untuk masingmasing faktor nampak pada tabel 2 berikut.

Tabel 2.Measure of Sampling Adequacy (MSA)

\begin{tabular}{lcc}
\hline \multicolumn{1}{c}{ Faktor } & Nilai MSA & \multicolumn{1}{c}{ Keputusan } \\
\hline Psikologis & $0,617>0,50$ & Dapat digunakan untuk analisis faktor \\
Objek & $0,682>0,50$ & Dapat digunakan untuk analisis faktor \\
Lingkungan & $0,621>0,50$ & Dapat digunakan untuk analisis faktor \\
\hline Berdasarkan tabel 2, maka dapat diketahui & Sehingga tidak terdapat faktor yang \\
bahwa faktor-faktor dalam penelitian ini & dikeluarkan dari model, dengan demikian \\
memiliki MSA > 0,50 dan faktor tersebut & faktor-faktor tersebut dapat dianalisis \\
adalah psikologis, objek dan lingkungan. & secara keseluruhan dan dapat dilanjutkan.
\end{tabular}


Untuk menentukan banyaknya faktor yang mempengaruhi persepsi siswa SMP Saraswati Singaraja terhadap evaluasi pembelajaran IPS Terpadu pada tahun ajaran 2017/2018, dapat dijelaskan oleh nilai persentase dari masing-masing faktor. Nilai Total Variance Explained digunakan untuk mengetahui kontribusi besarnya persentase dari ketiga faktor yang dianalisis. Hasil analisis faktor melalui SPSS menunjukkan persentase dari masing-masing faktor dapat dilihat pada tabel 3 berikut.

Tabel 3. Total Variance Explained

\begin{tabular}{lcrrrrr}
\hline & \multicolumn{3}{c}{ Initial Eigenvalues } & \multicolumn{3}{c}{ Extraction Sums of Squared Loadings } \\
Component & Total & \% of Variance & Cumulative \% & Total & \% of Variance & Cumulative \% \\
\hline 1 & 1.697 & 56.578 & 56.578 & 1.697 & 56.578 & 56.578 \\
2 & .713 & 23.767 & 80.344 & & & \\
3 & .590 & 19.656 & 100.000 & & & \\
\hline
\end{tabular}

Berdasarkan tabel 3, dapat diketahui bahwa persentase dari faktor psikologis memiliki eigenvalue sebesar 1,697 dengan nilai variance sebesar $56,578 \%$, faktor objek memiliki eigenvalue sebesar 0,713 dengan nilai variance sebesar 23,767\%, dan faktor lingkungan memiliki eigenvalue sebesar 0,590 dengan nilai variance sebesar 19,656\%. Menurut Yamin dan Kurniawan (2009:187) "Total variance explained menerangkan nilai persen dari varians yang mampu diterangkan oleh banyaknya faktor yang terbentuk." Berdasarkan hasil cumulative dari ketiga faktor tersebut yaitu sebesar $100 \%$, maka ketiga faktor tersebut mampu menjelaskan pengaruhnya sebesar 100\%. Jadi faktor psikologis, faktor objek, dan faktor lingkungan mempengaruhi persepsi siswa SMP Saraswati Singaraja terhadap evaluasi pembelajaran IPS Terpadu pada tahun ajaran 2017/2018.
Untuk menjelaskan faktor yang mempengaruhi persepsi siswa SMP Saraswati Singaraja terhadap evaluasi pembelajaran IPS Terpadu pada tahun ajaran 2017/2018, dapat dilakukan melalui ekstraksi faktor. Ekstraksi faktor dapat dijelaskan oleh total persentase varience dari masing-masing faktor utama. Faktorfaktor utama tersebut adalah faktor internal meliputi psikologis dan faktor eksternal meliputi objek dan lingkungan yang memiliki nilai parameter akar karakteristik terkecil eigenvalue $>1$. Untuk mengetahui distribusi dimensi yang belum dirotasi ke dalam faktor yang telah terbentuk maka dapat dilihat pada output SPSS 16.0 for windows (Rotated Component Matrix). Faktor yang mampu mempengaruhi persepsi siswa SMP Saraswati Singaraja terhadap evaluasi pembelajaran IPS Terpadu pada tahun ajaran 2017/2018, dapat dilihat pada tabel 4 berikut.

Tabel 4.Faktor-faktor yang mempengaruhi persepsi siswa SMP Saraswati Singaraja terhadap evaluasi pembelajaran IPS Terpadu pada tahun ajaran 2017/2018

\begin{tabular}{cccc}
\hline Variabel & Eigenvalue & Varianced Explained $(\%)$ & Factor Loading \\
\hline Psikologis & 1,697 & 56,578 & 0,778 \\
Objek & 0,713 & 23,767 & 0,704 \\
Lingkungan & 0,590 & 19,656 & 0,772 \\
\hline
\end{tabular}

Berdasarkan tabel 4, dapat dijelaskan bahwa faktor yang memiliki eigenvalue $>1$ adalah faktor psikologis, total nilai varianced explained dari faktorpsikologis dapat menjelaskan sebesar 56,578\%, dengan demikian $56,578 \%$ dari seluruh faktor yang ada, dapat dijelaskan oleh satu faktor yang terbentuk. Artinya faktor psikologis mampu mempengaruhi persepsi siswa SMP Saraswati Singaraja terhadap evaluasi pembelajaran IPS Terpadu pada tahun ajaran 2017/2018 sebesar 56,578\%. Menentukan nama faktor yang telah terbentuk untuk masing-masing faktor 
bersifat subjektif, kadangkala faktor yang memiliki nilai faktor loading tertinggi digunakan untuk memberikan nama faktor. Adapun nilai dari faktor loading dapat dilihat pada tabel 5 berikut.

Tabel 5. Hasil Analisis Rotated Component Matrix

\begin{tabular}{lr}
\hline & Component \\
& 1 \\
\hline Psikologis & .778 \\
Objek & .704 \\
Lingkungan & .772 \\
\hline
\end{tabular}

Berdasarkan tabel 5 di atas, masingmasing faktor tersebut memiliki faktor loading tertinggi di setiap komponen yaitu faktor satu faktor psikologis sebesar 0,778, faktor objek sebesar 0,704, dan faktor lingkungan sebesar 0,772.

Kedua, faktor yang paling dominan mempengaruhi persepsi siswa SMP Saraswati Singaraja terhadap evaluasi pembelajaran IPS Terpadu pada tahun ajaran 2017/2018. Berdasarkan pengujian hipotesis penelitian, untuk menentukan dimensi atau faktor yang paling dominan mempengaruhi persepsi siswa SMP Saraswati Singaraja terhadap evaluasi pembelajaran IPS Terpadu pada tahun ajaran 2017/2018, digunakan parameter koefisien varimax mendekati +1 dan -1 . Nilai yang mendekati +1 diawali oleh nilai 0,5 sedangkan nilai yang mendekati -1 diawali oleh $-0,5$. Secara lebih rinci hasil ringkasan rotasi dari matrik faktor memuat nilai varimax rotation, dapat dilihat pada tabel 6 berikut.

Tabel 6.Matriks Rotasi Hasil Analisis Faktor Dimensi atau faktor Varimax Rotation (\%) persepsi siswa

Psikologis 56,578

Berdasarkan tabel 6, dapat diketahui bahwa faktor yang paling dominan mempengaruhi persepsi siswa SMP Saraswati Singaraja terhadap evaluasi pembelajaran IPS Terpadu pada tahun ajaran 2017/2018 adalah faktor psikologis dengan nilai varimax rotation sebesar $56,578 \%$. Artinya kejelasan dari dimensi atau faktor persepsi siswa adalah faktor psikologis yang paling mendominasi sebesar $56,578 \%$.

\section{Pembahasan}

Berdasarkan hasil penelitian dapat diketahui faktor yang mempengaruhi persepsi siswa SMP Saraswati Singaraja terhadap evaluasi pembelajaran IPS Terpadu pada tahun ajaran 2017/2018 adalah faktor internal dan faktor eksternal. Faktor internal merupakan faktor yang berasal dari diri siswa, meliputi faktor psikologis. Faktor psikologis berkaitan dengan bagaimana pikiran bekerja dan berpikir serta merasa yang dapat mempengaruhi perilaku. Faktor psikologis yang ada di dalam diri siswa meliputi, pengalaman, perasaan, kemampuan berpikir, dan motivasi. Sedangkan faktor eksternal merupakan faktor yang berasal dari luar siswa meliputi, objek dan lingkungan. Objek dalam penelitian ini yaitu, pemberian evaluasi pembelajaran dan lingkungan dalam penlitian ini meliputi, suasana dan tempat. Suasana yang nyaman dan kondusif serta tempat yang bersih akan mempengaruhi siswa dalam mempersepsi suatu objek.

Hal ini sesuai dengan teori yang dinyatakan oleh Walgito (2003), bahwa faktor yang mempengaruhi persepsi siswa yaitu faktor internal meliputi, faktor psikologis dan faktor eksternal meliputi, objek dan lingkungan. Hasil penelitian yang ditunjukkan pada tabel 3 dapat dilihat bahwa masing-masing dari faktor tersebut berpengaruh terhadap persepsi siswa dari faktor psikologis sebesar 56,578\%, faktor objek sebesar 23,767\%, dan faktor lingkungan sebesar 19,656\%.

Berdasarkan pengujian hipotesis penelitian untuk menentukan faktor persepsi siswa yang paling dominan maka digunakan parameter varimax rotation dari faktor yang mempengaruhi persepsi siswa SMP Saraswati Singaraja terhadap evaluasi pembelajaran IPS Terpadu pada tahun ajaran 2017/2018 yang paling mendekati + 1 atau mendekati - 1 . Dari hasil rotasi terhadap faktor matriks pada varimax rotation, maka faktor yang paling mendominasi pada ketiga komponen utama yang terbentuk yaitu, faktor psikologis dengan nilai variance explained sebesar 
$56,578 \%$. Sehingga dapat disimpulkan bahwa faktor yang mendominasi persepsi siswa SMP Saraswati Singaraja terhadap evaluasi pembelajaran IPS Terpadu pada tahun ajaran 2017/2018 adalah faktor psikologis.

Faktor psikologis merupakan faktor yang dominan mempengaruhi persepsi siswa SMP Saraswati Singaraja terhadap evaluasi pembelajaran IPS Terpadu pada tahun ajaran 2017/2018. Faktor ini paling dominan dibandingkan faktor-faktor yang lain, disebabkan karena faktor psikologis merupakan faktor yang berasal dan ada di dalam diri siswa yang berkaitan dengan bagaimana pikiran bekerja, sehingga akan berpengaruh terhadap siswa dalam mempersepsi suatu objek dan berperilaku.

Hasil analisis faktor dalam penelitian ini memiliki persamaan dan perbedaan dengan penelitian sebelumnya. Penelitian yang dilakukan oleh Aditya Bayu Ariyantara (2016) dengan judul "faktor-faktor yang mempengaruhi persepsi siswa kelas VII SMP Negeri 4 Wates terhadap proses pembelajaran permainan bola basket" diperoleh persamaan menggunakan faktorfaktor yang mempengaruhi persepsi siswa yaitu faktor internal dan faktor eksternal. Namun dari faktor-faktor tersebut terdapat perbedaan variabel yang digunakan. Penelitian yang dilakukan oleh Aditya Bayu Ariyantara (2016) menggunakan faktor internal meliputi, perhatian, minat, pengalaman dan faktor eksternal meliputi, guru, materi, sarana dan prasarana, lingkungan sekolah, dan teman. Sedangkan penelitian ini menggunakanfaktor internal meliputi, faktor psikologis dan faktor eksternal meliputi, objek dan lingkungan. Selain itu, penelitian dari Aditya Bayu Ariyantara (2016) menggunakan analisis deskriptif, sedangkan penelitian ini menggunakan analisis faktor.

Hasil penelitian yang dilakukan oleh Aditya Bayu Ariyantara menunjukkan bahwa faktor internal yang mempengaruhi persepsi siswa berada pada kategori sangat baik dengan persentase $10 \%$ atau 4 siswa, kategori baik dengan persentase $12,5 \%$ atau 5 siswa, kategori cukup baik dengan persentase $42,5 \%$ atau 17 siswa, kategori kurang baik dengan persentase $27,5 \%$ atau 11 siswa, dan kategori sangat kurang dengan persentase $7,5 \%$ atau 3 siswa. Sedangkan faktor eksternal yang mempengaruhi persepsi siswa pada kategori sangat baik dengan persentase $7,5 \%$ atau 3 siswa, kategori baik dengan persentase $25 \%$ atau 10 siswa, kategori cukup baik dengan persentase 27,5\% atau 11 siswa, kategori kurang baik dengan persentase $35 \%$ atau 14 siswa, dan kategori sangat kurang dengan persentase $5 \%$ atau 2 siswa. Jadi, dapat disimpulkan bahwa faktor internal lebih mempengaruhi persepsi siswa kelas VII SMP Negeri 4 Wates terhadap proses pembelajaran permainan bola basket.

\section{SIMPULAN DAN SARAN Simpulan}

Berdasarkan hasil penelitian dan pembahasan, maka dapat di simpulkan yaitu faktor-faktor yang mempengaruhi persepsi siswa SMP Saraswati Singaraja terhadap evaluasi pembelajaran IPS terpadu pada tahun ajaran 2017/2018 adalah faktor internal meliputi, faktor psikologis memiliki eigenvalue sebesar 1,697 dengan nilai variance sebesar $56,578 \%$, faktor eksternal meliputi, faktor objek memiliki eigenvalue sebesar 0,713 dengan nilai variance sebesar $23,767 \%$ dan faktor lingkungan memiliki eigenvalue sebesar 0,590 dengan nilai variance sebesar 19,656\%.Faktor yang paling dominan mempengaruhi persepsi siswa SMP Saraswati Singaraja terhadap evaluasi pembelajaran IPS terpadu pada tahun ajaran 2017/2018 adalah faktor internal, meliputi faktor psikologis yang memiliki eigenvalue sebesar 1,697 dengan nilai variance sebesar $56,578 \%$.

\section{Saran}

Berdasarkan hasil penelitian yang telah disimpulkan di atas, peneliti memberikan saran yaitu bagi lembaga atau pihak sekolah dapat mengetahui faktorfaktor yang mempengaruhi persepsi siswa SMP Saraswati Singaraja terhadap evaluasi pembelajaran IPS terpadu, sehingga dapat menunjang hasil belajar yang lebih baik terhadap siswa. Bagi pendidik, diharapkan agar terus meningkatkan kreativitas dan pemahaman terkait dengan evaluasi pembelajaran. Sehingga peserta didik 
menjadi lebih bersemangat dan antusias dalam mengikuti evaluasi pembelajaran. Bagi kepentingan ilmiah dan peneliti lainnya yang hendak melakukan penelitian serupa, disarankan dalam penelitian selanjutnya dapat menambahkan variabel lain, sehingga hasil penelitian dapat digeneralisasi secara luas. Pada penelitan selanjutnya diharapkan melakukan penelitian yang lebih mendalam dengan memperhatikan faktor-faktor yang mempengaruhi persepsi siswa SMP Saraswati Singaraja terhadap evaluasi pembelajaran IPS Terpadu pada tahun 2017/2018.

\section{DAFTAR PUSTAKA}

Ariyantara, Aditya Bayu. 2016. "FaktorFaktor yang mempengaruhi persepsi Siswa Kelas VII SMP Negeri 4 Wates Terhadap Proses Pembelajaran Permainan Bola Basket". Tersedia pada http://eprints.uny.ac.id/37927/1/SKR IPSI.pdf (diakses tanggal 7 Desember 2017)

Astiti, Kadek Ayu. 2017. Evaluasi Pembelajaran. Yogyakarta: Andi

Firdaus, Aziz. 2012. Metode Penelitian. Tanggerang: Jelajah Nusa

Hamalik, Oemar. 2008. Kurikulum dan Pembelajaran. Jakarta: Sinar Grafika

Ikhsan, Arfan dan Muhammad Ishak. 2008. Akuntansi Keperilakuan. Jakarta: Salemba Empat

Mulyatiningsih, Endang. 2012. Metode Penelitian Terapan Bidang Pendidikan. Bandung: Alfabeta

Robbins, Stephen P dan Timothy A. Judge. 2008. Perilaku Organisasi. Jakarta: Salemba Empat

Sudaryono. 2012. Dasar-Dasar Evaluasi Pembelajaran. Yogyakarta: Graha IImu

Sugihartono, dkk. 2007. Psikologi Pendidikan. Yogyakarta: UNY Press
Sugiyono. 2010. Metode Penelitian Kuantitatif Kualitatif dan R\&D. Bandung: Alfabeta

Suliyanto.2005. Analisis Data dalam Aplikasi Pemasaran. Bogor: Ghalia Indonesia

Supranto, Johanes. 2010. Analisis Multivariat (Arti dan Interpretasi). Jakarta: PT. Rineka Cipta

Thoha, Miftah. 2003. Perilaku Organisasi Konsep Dasardan Aplikasinya. Jakarta: PT Raja Grafindo Persada

Walgito, Bimo. 2003. Psikologi Sosial Suatu Pengantar.Yogyakarta : Andi 2010. Pengantar Psikologi Umum. Yogyakarta: Andi

Yamin, Sofyan dan Heri Kurniawan. 2009. SPSS Complete Teknik Analisis Statistik Terlengkap dengan Software SPSS. Jakarta: Salemba Infotek 